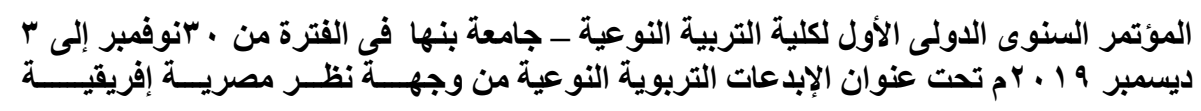

\title{
PREPARATION AND EVALUATION OF LOW- FAT BURGERS AND FORTIFIED BY CHICKPEA DURING FROZEN STORAGE
}

\author{
Omar Ahmed Emam
}

Eman Badawy Mehram
Ghada Mahmoud Elbassiony

Ahmed Hassan Saleh AlNajada

\section{Abstract}

This study aimed to prepare beef burger formulae with low-fat content, substituted of beef fat by chickpea flour with different levels $(\varepsilon, \wedge, \mid Y$ and $\%{ }^{10}$ ). The obtained results showed that: Beef burgers are considered as a good source of carbohydrate, protein, crude fiber, ash content, minerals (K, Fe and $\mathrm{Zn}$ ), antioxidant content (Polyphenols and flavonoids), essential amino acids , especially leucine and lysine and fatty acids (palmatic, stearic and oleic acid). Addition of chickpea flour to burgers decreased lipid oxidation (peroxide and thiobarbituric acid values) in either at zero time or during frozen storage. Addition of chickpea flour caused a decrease in total bacterial count, psychrophilic. Bacteria spore forming bacteria; fungi and yeasts in either at zero time or during frozen storage. During frozen storage, total bacteria, spore forming bacteria, fungi and yeasts were decreased. Sensory evaluation of burgers indicated that all samples were recorded highly acceptable score of color, texture, taste, order and overall acceptability by the panelists in either at zero time or at the end of storage.

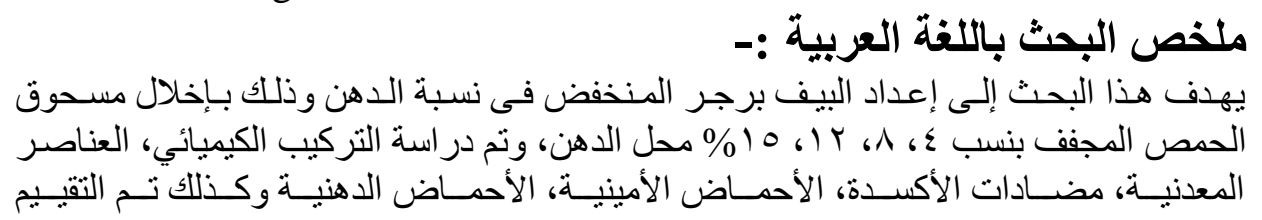




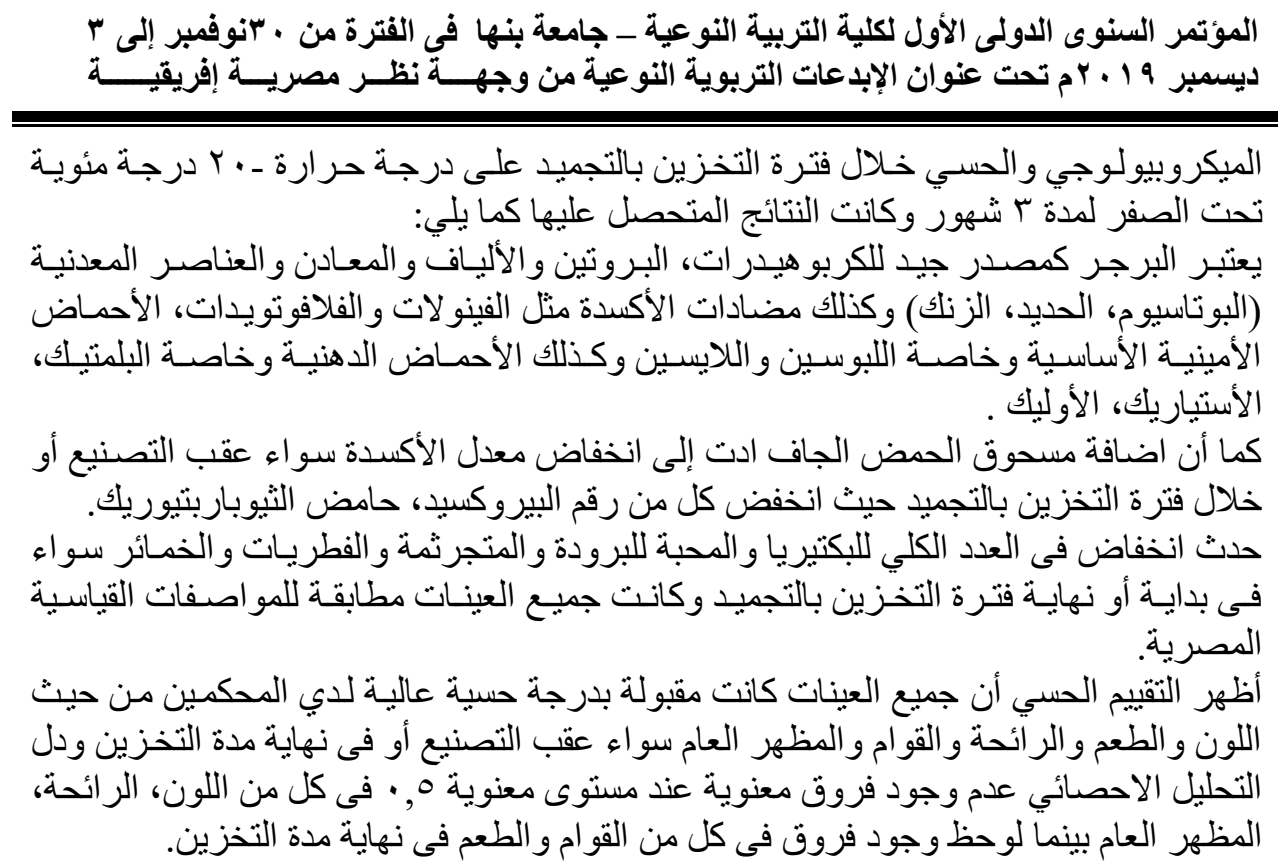

\section{INTRODUCTION}

Meat is a noble food for man, as it contributes in the diet, with proteins of high biological value, and essential fatty acids (Ferreria and Silva, $r \cdot \wedge)$. The burger is defined as an industrialized meat product obtained from the ground beef of the animals, added or not of adipose tissue and ingredients, molded and subjected to suitable technological process, with characteristic texture, color, taste and smell.

Meat products such as burgers, sausages and meatballs have been developed using spices, food resources and meat from beef, pork, duck and quail to add value to them (Ahmed and Nawab, r. is; Adzitey, r.1. and Kumari et al., r.10). Non-meat ingredients may be added to meat products with smaller quantities for binding, taste and flavor impartation (FAO,,$\ldots v$ and Mendiratta et al., $r ., r$ ).

High animal fat diets are associated with several types of obesity, coronary heart disease, cardiovascular diseases and hypertension (Serano et al., $r . . \vee$ and Ozvural and Vural, $r \ldots \wedge)$. Recently, change in consumer's 


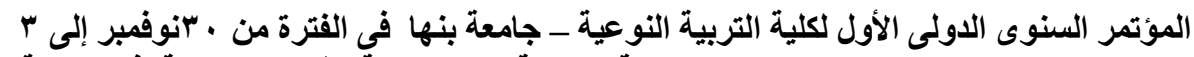

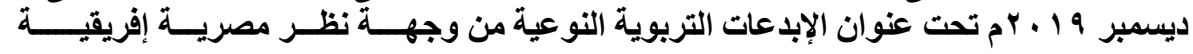

preferences had led to expensive research on Low-fat foods (Carrapiso, $r \cdot r v$ and Yang et al., r.rv).

The term "burgers" was taken originally from the word "hamburger" which presumably is a product that originated from Hamburg. Burger is one of the most important and popular meat products throughout the world. Most of European countries regulated that burgers should contain at least..$\%$ meat and $r .-r . \%$ of fat content. The production process of burgers is composed of mixing the meat with the curing, flavoring and coloring agents to obtain acceptable sensory and technological properties (AlMarazeeq et al., $\vdash . \wedge$ ).

Beef burgers is versatile, easy to prepare and relatively inexpensive (due to the use of low quality cuts of frozen meat), fat content is high (Savell et al., 1991). In recent years, the demand for low-fat meat products has been increased in order to avoid health risks associated with excessive fat intake (Kirchner et al., $r . .$. ).

Burgers are usually a feature of fast foods, most fast foods contain extremely high levels of trans fatty acids, which can lead to obesity, coronary disease and diabetes. Several studies have shown that the diets which rich in saturated fats and trans fats such as burger and fried meal caused an increase blood levels of low density lipoprotein (LDL) cholesterol that clogs the arteries (Zoradia et al., r. . ).

Several studies highlighted the possibility of replacing fat with another ingredient or a combination of ingredients known as fat replacers (Sayago Ayerdi et al., r... ).

Addition of vegetable in meat products can improve can improve sensory functional properties and nutritional quality (Turhan et al., $r . . v$ and Ali et al., r. 1). Moreover, vegetables could serve as binders, fillers, fat replacers and also sources of dietary fibers and natural antioxidants (Ali et al., r. l).

Chickpea (Ciceer arietum L.) is a major legume it is considered as a good source of plant protein in many countries of Asia and Africa Moreover, it is a suitable source of dietary protein and their relatively 


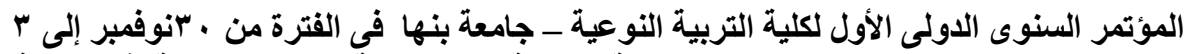

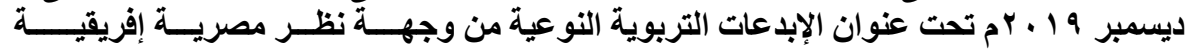

low levels of anti-nutritional factors (Friedman, 1999). Also, chickpea is an important pulse crop with a wide range of potential nutritional benefited because of its chemical composition. Tocopherols, well - established natural antioxidants, were found in chickpea seeds in relatively similar amounts across all genotypes. In addition, it is a rich source in minerals especially calcium (Marioli Nobile et al., r. r r).

Chickpea (Ciceer arietum, L.) is an important and cheap source of vegetable protein which could be used as a substitute for animal protein and also contributing to the human diet in several developing countries. In Egypt, chickpea seeds found to be usually consumed at the raw green and tender storage (unripe stage) called Malana, or in the form of mature dry seeds. After parching the dry seeds could be consumed as a popular snake food, whole or decorticated after cooking and processing in different ways (Alajaji and El-Adawy, r... ). Chickpea is an important food legume and it is a major ingredient in many human diets (Xu et al., r.1:). They found that carbohydrate and protein were two major components in all type seeds.

Evidence suggests that pulse products, possibly due to their fiber content, play a role in the reduced risk of cardiovascular diseases (CVDs) (Finley et al., r...v), obesity (Marinangeli and Jones, r.r), diabetes (Sievenpiper et al., r... ), and breast cancer (Velie et al., r...). In addition to incorporating cooked whole pulses into the diet, pulses made into flours are another nutritionally beneficially dietary option (USDA, r.1०).

This study aimed to prepare beef burger formulae with low-fat content, substituted of beef fat by chickpea flour with different percentages $(\varepsilon, \wedge, I r$ and $10 \%)$. Also, it could be obtained meat products with highly nutritional value, rich source of carbohydrate, fibers, and mineral contents, as well as it is the cheapest price and suitable for obesity and cardiovascular patient. In addition, chemical, physical, microbiological and sensory evaluations were studied during frozen storage period at $-r \cdot{ }^{\circ} \mathrm{C}$ for $r$ months. 


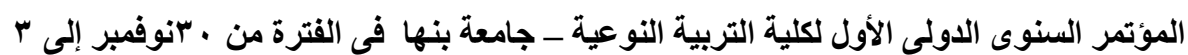

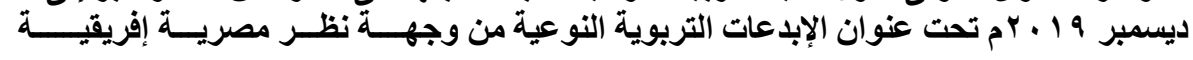

المجلة العلمية للاراسات والبحوث التربوية والنوعية العدد الحادى عشر فبراير · ب ب الجزء الثانى 170 


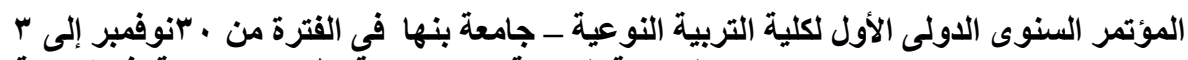

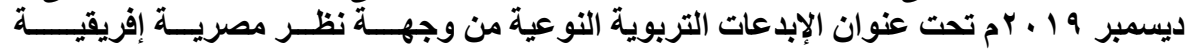

\section{MATERIALS AND METHODS}

\section{Materials}

Fresh Local beef meat from round cut was purchased from Cairo local market just after slaughtering, then transported covered with crushed ice to the laboratory of Specific Education, Benha University. Beef fat was also obtained from the same beef carcass. Grains of chickpea were cleaned from impurities, washed several time with clean tap water, soaked in water for about three days until swelling the grains and changed water to remove alkaloids. The grains of chickpea were blanched in amount of suitable water for $r \cdot \min$., then dried in an electric oven at $0 .{ }^{\circ} \mathrm{C}$. The grains were blended in an electrical grinder to give a flour with suitable granules. The flour was packed in polyethylene bags and kept in refrigerator at $\varepsilon^{\circ} \mathrm{C} \pm 1{ }^{\circ} \mathrm{C}$ until used.

Other materials such as starch, fresh minced onion and garlic, sodium chloride white pepper and spices were obtained from Cairo local market.

\section{Preparation of burgers}

Beef meat and fat were cut into small slices, and minced with crushed ice by using an electric minter. The other materials, chickpea flour, minced onion and garlic, potato starch, white pepper, sodium chloride and spices mixture were added (Fernández-López, et al., ץ.. ४) and mixed together then homogenized well. The preparing burgers were carried out as the described by Aleson-Carbonell et al., $(\uparrow \ldots \bullet)$ as illustrated in table (1). Chickpea flour was replaced by beef fat with different ratio $\left(\varepsilon_{.}, \Lambda_{.} \cdot, \mid r_{.} \cdot\right.$ and $\left.10 . . \%\right)$. These ingredients were homogenized well and formulation was pressed into burgers $(\wedge \cdot . \cdot \mathrm{g}$ weight, $\Lambda . \cdot \mathrm{cm}$ diameter and $1 . . \mathrm{cm}$ thickness) by using Molinex-burger machine. Samples were packed in polyethylene bags and stored at $-r \cdot{ }^{\circ} \mathrm{C}$ for three 


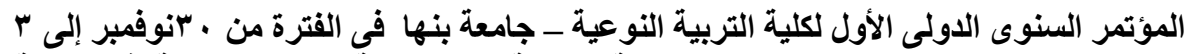

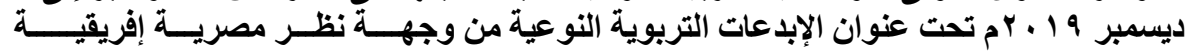

months. Before using, samples were thawed over night at $\varepsilon^{\circ} \mathrm{C}$. Chemical analysis were done immediately just after defrosting and the rest of tests were made on samples after cooking burgers in sunflower oil for $r$ min. for each side.

Table (1): The percentage of raw food ingredient used in prepared beef burger formulae.

\begin{tabular}{|c|c|c|c|c|c|}
\hline $\begin{array}{ll}\text { Formulae } \\
\text { Food ingredients }\end{array}$ & (1) & $(r)$ & $(r)$ & $(\varepsilon)$ & $(0)$ \\
\hline Minced beef meat & $7 .$. & $7 \ldots$ & $7 \ldots$ & $7 \ldots$ & $7 .$. \\
\hline Minced beef fat & १ᄉ.. & $1 \leqslant$. & $1 \cdots$ & १.. & r.. \\
\hline Chickpea flour & $\cdots$ & $\varepsilon$. & $\wedge .$. & Ir.. & $10 .$. \\
\hline Potato starch & $1 \cdots$ & $1 \ldots$ & $1 \cdots$ & $1 \cdot$. & $1 \ldots$ \\
\hline Sodium chloride & .0 &. .0 &. .0 &. .0 & $\cdot .0$ \\
\hline White pepper &. .0 &. .0 & $\cdot .0$ &. .0 & $\cdot .0$ \\
\hline Spices mixture & 1. & $1 .$. & $1 .$. & $1 .$. & $1 .$. \\
\hline Crushed ice & $1 \ldots$ & $1 \ldots$ & $1 \ldots$ & $1 \ldots$ & $1 \ldots$ \\
\hline
\end{tabular}

\section{Chemical analysis}

Moisture content, protein, crude fiber and ash content of samples were determined according to the method described by AOAC, $(\uparrow \ldots \bullet)$. Results expressed as $\mathrm{g} / \mathrm{l}$. g on dry weight basis. Carbohydrates and total energy were calculated according to FAO/WHO/UNU, ( $৭ \wedge \diamond)$. Results of total energy were calculated as k.cal./ $\cdots \mathrm{g}$ on dry weight. Total lipids were determined as described by Bligh and Dyer, ( $99 \diamond)$. Minerals of prepared beef burgers ( $\mathrm{Ca}, \mathrm{K}, \mathrm{Na}, \mathrm{Fe}$ and $\mathrm{Zn}$ ) were determined according to the method described by American Association of Cereal 


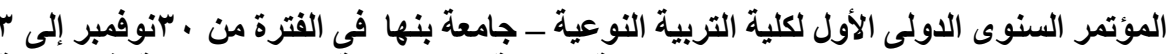

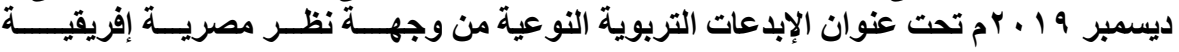

Chemists, (1৭^५) and Kirleis et al., ( $19 \wedge \varepsilon)$ by using Atomic Absorption. Results expressed as $\mathrm{mg} / \mathrm{l}$.. g on dry weight basis.

Total phenols of beef burgers was determined as described by Velioglu et al., ( $99 \wedge$ ). Results were expressed as $\mathrm{mg}$ gallic acid equivalents $/ 1 \cdot \mathrm{g}$. Total flavonoids was carried out as the method of Ordon et al., ( $\uparrow \ldots \curlyvee)$. Results expressed as quercein $\mathrm{mg} / \mathrm{g}$ dry matter.

Amino acids were determined according to the methods described by Winder and Egyum, ( $(94 \checkmark)$ and AOAC, $(r+1\})$ by using High Performance Amino Acids Analyzer Biochron r. Pharmacia Biotech. Food Technology Institute, Giza, Egypt. Results expressed as g/ $\ldots$ g on dry matter

Fatty acids of prepared beef burgers were determined according to the method described by AOAC, $(\uparrow \ldots)$ by using Gas chromatograph with FID detector in Agricultural Research Center, Food Technology Institute, Giza, Egypt.

Peroxide values of burgers were determined according to the method described by AOAC, $(\boldsymbol{r} \ldots \bullet)$. Results expressed as mill.equivalent $/ \mathrm{kg}$ lipids. Meanwhile, thiobarbituric acid values (TBA) were carried out as the method described by AOCS, (19१^). Results as expressed as mg malonaldehyde/kg sample. Total bacterial count; psychrophilic bacteria, spore forming bacteria; fungi and yeasts were determined according to ICMSF, ( $१ \vee \wedge)$. Sensory evaluation of prepared beef burgers were carried out as described by Watts et al., ( $(१ \wedge$ $)$. Statistical analysis of the obtained data for three replicates was carried out by SPSS, ( $१$ १^). Values of $\mathrm{p} \leq \ldots$. were considered as significantly difference. 


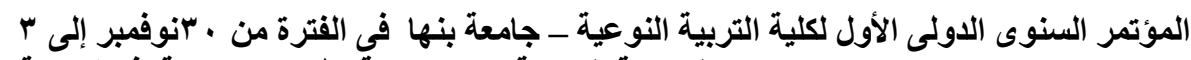

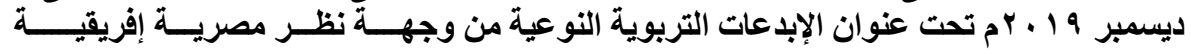

\section{RESULTS AND DISCUSSION}

\section{Chemical composition}

Chemical composition of both fresh local beef meat and chickpeas flour was shown in table $(r)$. The obtained results showed that beef meat was consisted of $\vee r . \circ \uparrow \%$ moisture content, $\vee \vee .91 \%$ crude protein, $\vee . .0 \%$ fat,. $.09 \%$ crude fiber, . . $01 \%$ ash content and . . $₹ \uparrow \%$ carbohydrate $(\mathrm{g} / \mathrm{l}$. $\mathrm{g}$ on fresh weight basis).

On the other hand, chickpea flour was composed of rะ.r \% plant

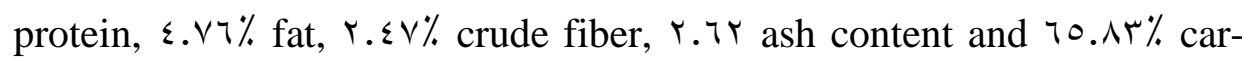
bohydrate $(\mathrm{g} / \mathrm{l} \cdots \mathrm{g}$ on dry weight basis. These results are confirmed by Atul et al., $(r+11)$ and Al-Shemary, Fatma, $(\uparrow+19)$. Generally, chickpea is considered as a good source of protein, carbohydrate, crude fiber and ash content. Total energy of local fresh meat was 1 ז $. \wedge \mathrm{k} . \mathrm{cal} / 1 \cdots \mathrm{g}$ on fresh weight basis. Meanwhile, total energy of chickpea flour was $\varepsilon \cdot r . \varepsilon \mathrm{k} . \mathrm{cal} / \mathrm{l} \cdot$. g on dry weight basis.

Table ( $\uparrow$ ): Chemical composition of both beef meat and chickpea flour.

\begin{tabular}{|c|c|c|}
\hline $\begin{array}{ll}\text { Constituents } & \text { Ingredients } \\
\end{array}$ & $\begin{array}{c}\text { Local fresh beef } \\
\text { meat } \\
(\mathrm{g} / \mathrm{l} \ldots \text { fresh weight })\end{array}$ & $\begin{array}{l}\text { Chickpea flour } \\
\text { (g/1 } \ldots \text { dry weight })\end{array}$ \\
\hline Moisture \% & Vr.or & $V .9 Y$ \\
\hline Crude protein $\%$ & $|v .9|$ & TE.Tr \\
\hline Fat $\%$ & $V . .0$ & $\varepsilon . V 7$ \\
\hline Crude fiber $\%$ &. .09 & T.EV \\
\hline Ash\% &. .01 & r.tr \\
\hline Carbohydrates\% &..$\leqslant r$ & T0.人 \\
\hline
\end{tabular}




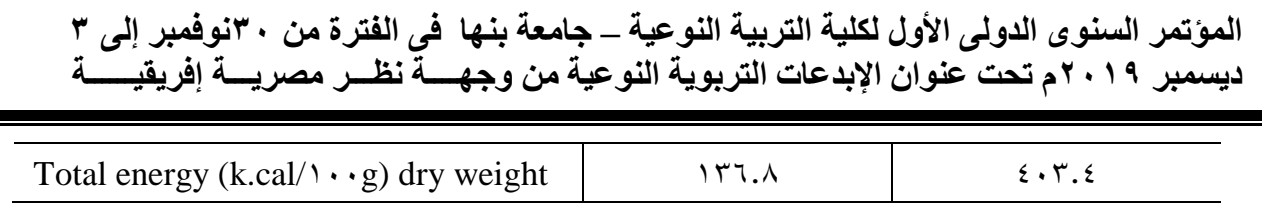

Table $(Y$ ) illustrates chemical composition of prepared beef burgers replaced of beef fat by chickpea flour during frozen storage period moisture percentage of prepared beef burger formulae replaced of beef fat by chickpea flour with different ratio $\left(\varepsilon_{.}, \Lambda_{.} \cdot, 1 Y_{.}\right.$and $\left.10 . \%\right)$ during frozen storage at $-r \cdot{ }^{\circ} \mathrm{C}$ for $r$ months. The results showed that the moisture content was ranged from $\leqslant \vee .1 \%$ to $07 . \% \%$, the highest percentage of moisture was found in control samples and the lowest was in formula ( 0 ) which contained $10 . \%$ chickpea flour. The higher addition of chickpea flour, the lower percentage of moisture content was observed. During frozen storage period, the moisture content was gradually decreased as the prolonged storage time proceeded until reached between $\leqslant r . \vee \%$ and $0 . .1 \%$. Also, moisture content was decreased as the level of chickpea flour increased. The same conclusion was found by Mehram, Eman, $(r+\mid \vee)$ and Morcy, Hayam, $(r+\mid \vee)$. The decrease of moisture content during frozen storage may be due to the escape of a moisture in the drip loss during thawing (Emam, 1 $\wedge \wedge \vee$ ).

The obtained results indicated that crude protein was ranged from $\{7$. to $0 . .7 \% \mathrm{~g} / \mathrm{l} \cdot \mathrm{g}$ on dry weight basis, control sample was recorded the lowest percentage of protein, meanwhile, formula $(0)$ was the highest percentage. The protein content was increased as the level of chickpea increased, this increase of crude protein could be due to that chickpea is rich source of plant protein as shown in the previously results in table $(r)$. Chickpea is considered as a good source of plant protein (Atul et al., $r \cdot 11)$.

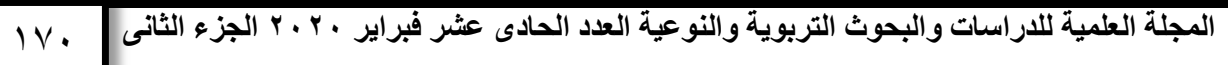




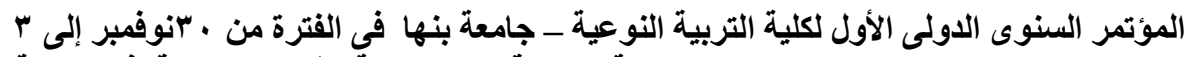

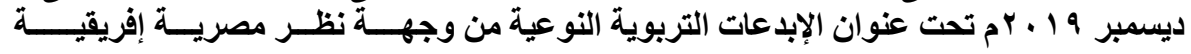

It is evident from the results that fat percentage of prepared beef burgers was ranged from $1 \leqslant .90$ to $\uparrow \wedge . . \curlyvee \%$, the highest percentage of fat was found in control sample (without chickpea flour) and the lowest percentage was in formula ( $(0)$ i.e fat content was decreased as the level of chickpea flour increased. This decrease of fat could be due to that chickpea flour contained low fat percentage as shown in the previously results in table $(r)$.

The results also indicated that carbohydrate of prepared beef burgers was ranged from $1 \vee .79$ to $r \varepsilon_{.} . \varepsilon \% \mathrm{~g} / \mathrm{l}$. g on dry weight basis. Formula ( $(0)$ was the highest percentage of carbohydrate. Also, chickpea is a rich source of carbohydrate (Al-Shemary, Fatma, Y. 19).

It is obvious from the results that crude fiber of prepared beef burgers was ranged between $\uparrow . \cdot$ and $\varepsilon . \vee \uparrow \%(g / l \cdots g$ on dry weight basis). The highest value of crude fiber was found in formula ( $(0)$ and control sample recorded the lowest value. This could be that chickpea is considered as a good source of crude and dietary fibers (Al-Shemary, Fatma, r 19 ).

The results also showed that ash content of prepared burgers was ranged from r. . + to $0 . \vee \% \mathrm{~g} / \mathrm{l} \cdot \mathrm{g}$ on dry weight basis. Ash content was increased as the level of chickpea flour increased. This increase could be due to that chickpea is a rich source of ash content as illustrated in the previously results $n$ table $(r)$. In addition, chickpea is a good source of minerals (Marioli Nobile et al., $r \cdot 1 r$ ).

It was found that both protein and fat percentage of all prepared burgers were decreased during frozen storage until reached from $\leq r . r$ to $\varepsilon \vee . r \%$ in crude protein and from $11 . \vee$ to $r$.$r \%$ in fat content. This decrease of protein may be due to the part of total nitrogen which escape in 
the drip loss through thawing process. The same trend of results was noticed by (Mehram, Eman $r \cdot 1 v$ ).

Both fat and protein content were decreased in contrast, carbohydrate, fibers and ash content were increased during frozen storage period. These results are in agreement with those obtained by Morcy, Hayam, $(\uparrow \cdot \mid \vee)$, and Ayed, Najlh, $(\uparrow \cdot \mid \wedge)$. Finally, it could be concluded that prepared burgers by replaced chickpea flour were considered as a good source of carbohydrate, protein, crude fibers and ash content. Meanwhile, it contained low-fat content and formula $(0)$ showed that best results.

Table ( $r)$ : Chemical composition of prepared beef burgers replaced of beef fat by chickpea flour (CF) during frozen storage.

\begin{tabular}{|c|c|c|c|c|c|}
\hline $\begin{array}{l}\text { Formulae } \\
\text { Constituents }\end{array}$ & (1) Control & $\begin{array}{l}(r) \leq \% \\
(\mathbf{C F})\end{array}$ & $\begin{array}{l}(r) \wedge \% \\
(\mathbf{C F})\end{array}$ & $\begin{array}{l}(\varepsilon) 1 r \% \\
(\mathrm{CF})\end{array}$ & $\begin{array}{c}(0) \\
10 \%(C F)\end{array}$ \\
\hline \multicolumn{6}{|c|}{ Moisture content } \\
\hline Zero time & 07.r & or. E & $01 . V$ & $\leqslant \wedge .0$ & $\leq \vee .1$ \\
\hline r months & $0 . .1$ & $\varepsilon \wedge . r$ & $\leq ૫ . Y$ & $\leq \varepsilon .0$ & $\leq r . v$ \\
\hline \multicolumn{6}{|c|}{ Crud Protein (\%) } \\
\hline \multicolumn{6}{|c|}{ Fat $(\%)$} \\
\hline Zero time & rA. tr & rV.rV & Y0.07 & $1 \wedge . \leqslant 7$ & $1 \leq .90$ \\
\hline r months & זч. & Yo.A & $r \leq .1$ & 17.r & $11 . \mathrm{V}$ \\
\hline \multicolumn{6}{|c|}{ Ash (\%) } \\
\hline Zero time & r.l. & ะ.9. & $0 . r$. & 0.0 & $0 . v$. \\
\hline r months & r.. & 0.7 & 7.1 & 7. & v.. \\
\hline \multicolumn{6}{|c|}{ Crude fiber $(\%)$} \\
\hline Zero time & $r . .0$ & r.r. & $r .00$ & r.9r & s.vi \\
\hline r months & r.. & $\varepsilon . \wedge$ & 7.0 & 7.1 & T.ร \\
\hline \multicolumn{6}{|c|}{ Carbohydrates $(\%)$} \\
\hline Zero time & 19.人r & IV.VT & 18.79 & rT.人 & $r \varepsilon \ldots \varepsilon$ \\
\hline r months & $r \cdot . \cdot$ & $r \ldots$ & $r . . v$ & ro.0 & Y^.T \\
\hline
\end{tabular}




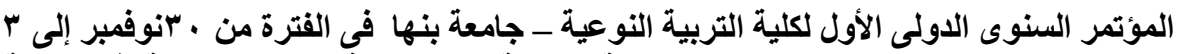

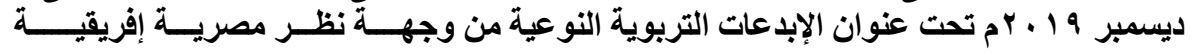

Results expressed as $\mathrm{g} / \mathrm{l}$.. g on dry weight

\section{Antioxidant content}

Table ( $\varepsilon$ ) shows antioxidant contents of prepared beef burgers substituted of beef fat by chickpea flour with different ratio $(\varepsilon, \Lambda, I r$ and $10 \%$ ). The results revealed that phenols of beef burgers was ranged between $1 \cdot \wedge .91$ to $109 . \leqslant \leqslant \mathrm{mg} / 1 \cdots \mathrm{g}$ gallic acid equivalent. The highest value of total phenolics was found in formula $(Y$ ) contained $\leqslant$ chickpea flour. On the other hand total flavonoids was ranged from 10. ro to $\leq r . \wedge$ $\mathrm{mg} / \mathrm{l}$. g querctin equivalent, the highest value was found in formula ( $(0)$ and the lowest one was in control samples (without addition of chickpea flour). It is evident from the results that the higher addition of chickpea flour, the higher value of total flavonoids was noticed. This results could be due to the chickpeas is a good source of antioxidant contents (AlShemary, Fatma, r+19).

Chickpeas is a rich source of tochopherols (Boschin and Arnolds, r. 11$)$. In addition, El-Nahas, ( $r \ldots r$ ) found that both green and dry chickpeas is a good source of antioxidant contents, especially chlorogenic acid which is considered the most important of the cinamics group. Generally, beef burgers by the addition of chickpea flour is considered as a good source of antioxidant contents and formula ( $(0)$ was the best results in both polyphenols and flavonoids.

Table ( $\varepsilon$ ): Antioxidant content of prepared beef burgers, replaced of beef fat by chickpea flour.

\begin{tabular}{|c|c|c|c|c|c|}
\hline$\underbrace{\text { Treatments }}_{\text {Antioxidants }}$ & (1) Control & $\begin{array}{c}(r) \\
\leqslant \%(C F)\end{array}$ & $\begin{array}{c}(\boldsymbol{r}) \\
\wedge \%(\mathbf{C F})\end{array}$ & $\begin{array}{c}(\varepsilon) \\
1 \times \%(C F)\end{array}$ & $\begin{array}{c}(0) \\
10 \%(C F)\end{array}$ \\
\hline Total phenols & $\mid r \leqslant .94$ & $109 . \leqslant \varepsilon$ & $119.1 \%$ & $1 \cdot 1.91$ & $\mid$ |r..T| \\
\hline
\end{tabular}




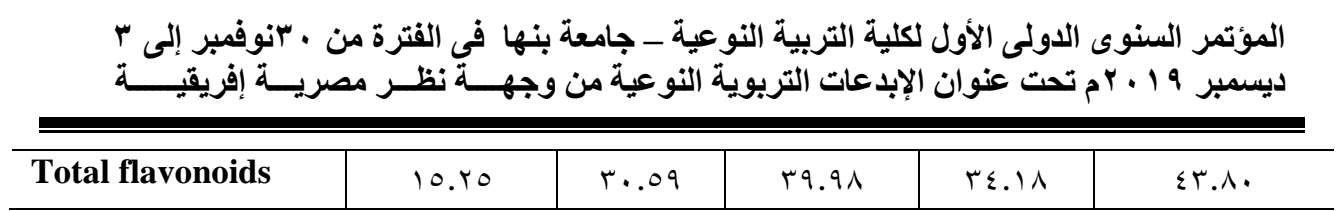

* Results expressed as $\mathrm{mg} / 1 \cdots \mathrm{g}$ (galic acid equivalent) on dry weight basis.

* Results expressed as $\mathrm{mg} / \mathrm{l}$. g (Querectin equivalent) on dry weight basis

\section{Minerals}

Table ( $\bullet$ ) illustrate mineral contents of prepared beef burger formulae substituted of beef fat by chickpea flour with different levels ( $\varepsilon . \cdot$, A.•,,$r_{.}$. and $10 . \%$ ). Macroelements of $\mathrm{Ca}$ of burger samples was ranged from $19.1 r$ to $r \wedge .10 \mathrm{mg} / 1 \cdots \mathrm{g}$ on dry weight basis, while $\mathrm{P}$ was ranged between $r q . \cdot$ and $\Sigma \vee . \cdot \mathrm{mg} / \mathrm{\cdots} \cdot \mathrm{g}$ dry matter. It is obvious from the results that $\mathrm{Mg}$ was ranged from $\neg . .1 \wedge$ to $\vee r . \vee 9 \mathrm{mg} / \curlywedge \cdots \mathrm{g}$ dry weight, the highest value was in formula $(0)$ which contained $10 . . \%$ and the lowest value was found in control sample (without addition of chickpea flour). Also, $\mathrm{K}$ of burger samples was ranged between 19.57 and 11 7. $\mathrm{mg} / \mathrm{l} \cdot \mathrm{g}$ on dry weight, the highest value was also found in formula ( $(0)$ and the lowest one was in control samples. It is worthy to mention that both $\mathrm{Mg}$ and $\mathrm{K}$ were increased as the level addition of chickpea increased. This results could be due to that chickpea is considered as a good source of studied minerals (Marioli Nobile et al., $r+1$ \%).

On the other hand, microelements of Fe of prepared burger samples was ranged from $\vee .1$ to $11 . \mathrm{r}$, while $\mathrm{Zn}$ was ranged between $\mathrm{V} .0 \mathrm{~N}$ and $11.9 \mathrm{r} \mathrm{mg} / \mathrm{l} \cdot \mathrm{g}$ dry matter. Formula (0) was the highest value of Fe. This results could be due to that chickpea is a good source of microelements (Mariol Nobile et al., $r \cdot 1 r$ ). It is worthy to mention that consuming $1 \cdots \mathrm{g}$ from all prepared beef burgers could cover the daily requirements of $\mathrm{Fe}$ and $\mathrm{Zn}$ human consumption. Prepared beef burgers by using 


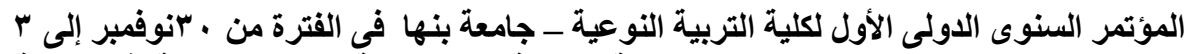

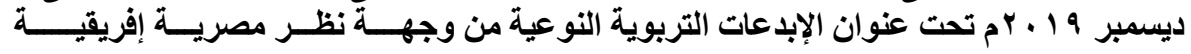

chickpea flour is considered as a good source of Fe, $\mathrm{K}$ and $\mathrm{Mg}$ and formulae ( 0 ) was the best formula of these minerals.

Table ( $\bullet$ ): Mineral contents of prepared beef burgers, replaced of beef fat by chickpea flour (CF).

\begin{tabular}{|c|c|c|c|c|c|}
\hline Minerals & $\begin{array}{l}\text { (1) Con- } \\
\text { trol }\end{array}$ & $\begin{array}{c}(r) \\
\varepsilon \%(\mathbf{C F})\end{array}$ & $\begin{array}{c}(\stackrel{\mathrm{r}}{)}) \\
\wedge \%(\mathrm{CF})\end{array}$ & $\begin{array}{c}(\xi) \\
14 \%(\mathbf{C F})\end{array}$ & $\begin{array}{c}(0) \\
10 \%(C F)\end{array}$ \\
\hline \multicolumn{6}{|c|}{ Macroelements (mg/ $\cdots$ ’g dry weight) } \\
\hline $\mathbf{C a}$ & TO.YY & 19.14 & $r \cdot . r \wedge$ & $r 7.91$ & rA.10 \\
\hline $\mathbf{P}$ & rq. & «!. & $\varepsilon r_{.}$ & $\varepsilon \vee$. & rq. \\
\hline Mg & $7 \cdot .11$ & 70.91 & TA.rV & 79.11 & $V Y . V q$ \\
\hline $\mathbf{K}$ & 19.57 & $\Delta r .+T$ & $117 . r$ & $1 \cdot 7 . r$ & $117 . r$ \\
\hline \multicolumn{6}{|c|}{ Microelements (ppm / ’ ’g dry weight) } \\
\hline $\mathbf{F e}$ & $\wedge . \wedge \vee$ & $\mathrm{V} .1$ & $1 \cdot . r v$ & 11.9 & $11 . Y V$ \\
\hline $\mathbf{Z n}$ & 11.94 & $\vee .01$ & $\wedge .1 \varepsilon$ & $9 . T^{\prime}$ & $\wedge .+1$ \\
\hline
\end{tabular}

Results calculated as $\mathrm{mg} / \mathrm{l}$. g on dry weight basis.

Amino acids

Table ( 7 ) illustrates amino acid composition of prepared beef burger formulae substituted of beef meat by chickpea flour during frozen storage period at $-r \cdot{ }^{\circ} \mathrm{C}$ for $r$ months. The results showed that there are iv amino acids could be separated and identified by Amino Acid Analyzer. These amino acids are $1 \cdot$ essential and $V$ non-essential amino acids. The major essential amino acids are leucine which ranged from $r . \leqslant$ to $\varepsilon . \vee \vee \mathrm{mg} / l \cdots$ gram on dry weight basis, followed by lysine ( $r . \uparrow \wedge$ ₹. $\vee$ ) $\mathrm{mg} / \mathrm{l} \cdots \mathrm{g}$ on dry weight basis. On the other hand, total essential amino acids was ranged between 19.90 and $r$ r.Ar $\mathrm{mg} / 1 \cdots \mathrm{g}$ on dry weight gain, the highest percentage was found in control sample and the lowest one was in formulae $(\varepsilon)$. This results could be due to that beef meat is a rich source in essential amino acids. It is evident from the abovementioned results that total non-essential amino acids was ranged from $r$ r. 19 to $r \tau . \& 1 \mathrm{mg} / \mathrm{l} \cdot \mathrm{g}$ on dry weight basis. The predominant 


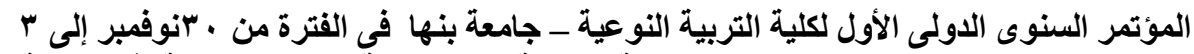

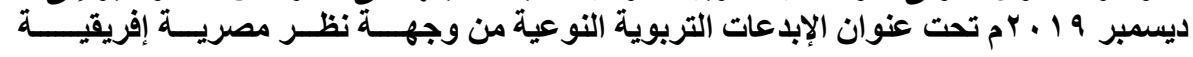

non-essential amino acids of prepared beef burgers was glutamic acid

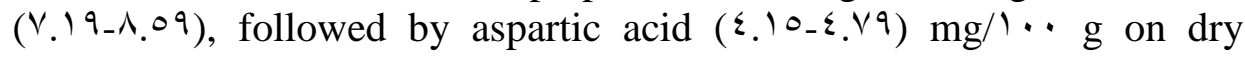
weight basis.

In addition, total amino acids of prepared beef burgers ranged between $\leqslant r .1 \leq$ and $\leqslant 9 . r r \mathrm{mg} / \mathrm{l} \cdot \mathrm{g}$ on dry weight. The highest value was found in control samples and the lowest one was in formula $(\varepsilon)$ which contained $1, \%$ chickpea powder. This results may be due to that beef meat is considered as a good source of animal protein and essential amino acids (Emam, 199. , and Ferreria and Silva, $r \cdot 1 \wedge$ ). It is worthy to mention that, total essential amino acids and total amino acids were slightly decreased as the percentage addition of chickpea flour increased. All prepared beef burger formulae are considered as a good source of essential amino acids especially, leucine and lysine, as well as control sample was recorded the best results of EAA. 


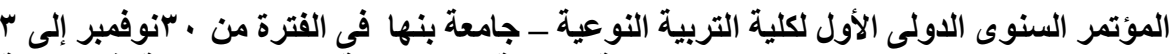

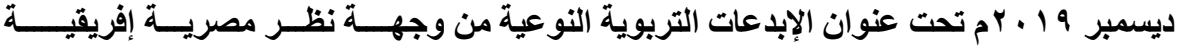

Table ( $\urcorner$ ): Amino acids of prepared burgers substituted of beef fat by chickpea flour.

\begin{tabular}{|c|c|c|c|c|c|}
\hline Amino acids & $\begin{array}{c}\text { (1) } \\
\text { Control }\end{array}$ & $\begin{array}{c}(r) \\
\leqslant \%(C F)\end{array}$ & $\begin{array}{c}(r) \\
\wedge \% \\
(\mathbf{C F}) \\
\end{array}$ & $\begin{array}{l}(\varepsilon) \\
1 r \% \\
(\mathbf{C F})\end{array}$ & $\begin{array}{c}(0) \\
10 \%(\text { CF })\end{array}$ \\
\hline \multicolumn{6}{|c|}{ Essential amino acids (EAA) } \\
\hline Therionine (THR) & Y.rE & r.. $T$ & r.r. & $1 . \leqslant \wedge$ & 1.17 \\
\hline Valine (VAL) & r.00 &.$r_{7}$ & r.r. & r.Ir & t.re \\
\hline Isoleucine (ILE) & T.YT & r.l. & r.17 & 1.90 & r.. 1 \\
\hline Leucine (LEU) & $\varepsilon . \cdot v$ & $r .71$ & r.10 & r.乏) & r.or \\
\hline Tyrosine (TYR) & $1 . \leqslant V$ & 1.79 & 1.174 & $\cdot . \wedge 9$ & $1.0 \leqslant$ \\
\hline Phenyl alanine (PHE) & 1.11 & r... & r.. $\varepsilon$ & 1.10 & $1 . \wedge \mathrm{V}$ \\
\hline Histidine (HIS) & $1 . \wedge \varepsilon$ & $1 . V r$ & $1 . \vee \wedge$ & 1.70 & 1.77 \\
\hline Lysine (LYS) & $\varepsilon .1 V$ & r.or & $r . v 1$ & r.Y人 & 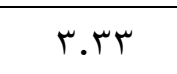 \\
\hline Cystine (CYS) &.$\vee \wedge$ &. .07 &. .00 & r.19 & $1 . .1$ \\
\hline Methionine (MET) & $1 . \leqslant 7$ & 1.47 & $1 . \varepsilon 1$ & $1.1 r$ & 1.99 \\
\hline Total EAA & rT.AT & $r \cdot . \cdot$ & YI.VA & 19.90 & $r \cdot . T_{1}$ \\
\hline \multicolumn{6}{|c|}{ Non-essential amino acids (NEAA) } \\
\hline Aspartic (ASP) & $\varepsilon . \vee q$ & $\varepsilon . \mu$ & $\varepsilon .71$ & s.rq & $\varepsilon .10$ \\
\hline Serine (SER) & 1.99 & 1.20 & r..r & $1 .+7$ & 1.09 \\
\hline Glutamic acid (GLU) & $\wedge .09$ & V.VT & A.r & V.19 & $\vee . \wedge 0$ \\
\hline Glycine (GLY) & r.Ar & r. $\leqslant 7$ & T. TV & r.01 & r. .00 \\
\hline Alanine (ALA) & r.r) & r. $\varepsilon \varepsilon$ & r.^r & ז.r & r.tr \\
\hline Arginine (ARG) & $r . r)$ & r.) & $r . \varepsilon r$ & r.) & $r .90$ \\
\hline
\end{tabular}




\begin{tabular}{|c|c|c|c|c|c|}
\hline Proline (PRO) & 1.1 & r.l. & r.10 & $1.0 \leqslant$ & r..r \\
\hline Total NEAA & Yฯ.ร1 & $r \leq .$. & rV.O & rr. & $r \leq . \leq \varepsilon$ \\
\hline Total AA & $\varepsilon q . r \mu$ & $\varepsilon \varepsilon \ldots$ & $\leqslant 9 . Y \wedge$ & $\varepsilon \mu .1 \varepsilon$ & $\leqslant \varepsilon .70$ \\
\hline
\end{tabular}

Results expressed as $\mathrm{g} / \mathrm{l}$ g on dry weight

\section{Fatty acids}

Data in table $(\vee)$ illustrates the fatty acid composition of lipids extracted from prepared beef burger formulae substituted of beef fat by chickpea flour with different ratio ( $\varepsilon, \wedge, I r$ and $10 \%$ ) during frozen storage at $-r \cdot{ }^{\circ} \mathrm{C}$ for $r$ months. The obtained results showed that there are nineteen fatty acids could be separated and identified by Gas liquid Chromatography (GLC). These fatty acids are, five saturated fatty acids (SFA), twelve unsaturated fatty acids (USFA) and two odd carbon number fatty acids.

It is obvious from the results that three fatty acids are $\left(\mathrm{C}_{1 \%: .}, \mathrm{C}_{1 \wedge: .}\right.$ and $\left.C_{(\wedge: 1)}\right)$ only are predominant and constituents $\wedge r . \wedge \wedge \%$ of the total fatty acids, while others are in minor quantities i.e the remaining sixteen fatty acids constituents only $1 \mathrm{~V} .1 \mathrm{Y} \%$ of the total fatty acids. The three major

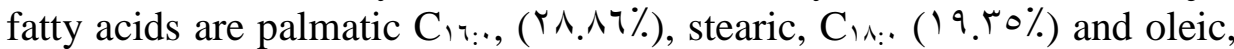
$\mathrm{C}_{\wedge_{1: 1}}(\Gamma \leqslant .7 \vee \%)$. There are two odd carbon number fatty acids, pentaenoic,

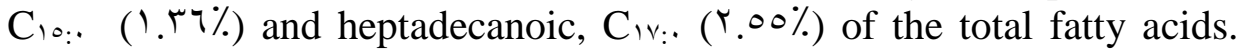
Total saturated fatty acids was ranged from $r \wedge . r$ to $0 \leqslant .0 r \%$ of the total fatty acids, while unsaturated fatty acids was ranged between $\leqslant 1.1$ and ०^. 0 r\% of the total fatty acids.

It is worthy to mentioned that total saturated fatty acids of beef burger was decreased as the level addition of chickpea flour increased. In contrast, unsaturated fatty acids increased with the increasing of chickpea flour. However, linoleic acid $C_{\wedge A: r}$ was ranged between $r . \wedge r$ and $11.00 \%$ of the total fatty acids. The highest percentage was found in formula $\left({ }^{\circ}\right)$ and the lowest was found in control samples. 
KS ratio of lipid extracted from prepared beef burgers was increased as the level chickpea flour increased. This increase could be due to that chickpea contained unsaturated fatty acids (Gul et al., $r \cdots \wedge$ and Marioli Nobil, $r \cdot 1 r$ ). Prepared beef burgers replaced of beef fat by chickpea flour is considered as a good source of fatty acids, especially palmatic, stearic and oleic acid.

Table ( $\vee$ ): Fatty acid composition of prepared beef burgers substituted of beef fat by chickpea flour.

\begin{tabular}{|c|c|c|c|c|c|}
\hline Fatty acids & $\begin{array}{l}\text { (1) Con- } \\
\text { trol }\end{array}$ & $\begin{array}{c}(r) \\
\varepsilon \%(C F)\end{array}$ & $\begin{array}{c}(r) \\
\wedge \% \\
(\mathbf{C F}) \\
\end{array}$ & $\begin{array}{l}(\varepsilon) \\
1 \times \% \\
(\mathbf{C F})\end{array}$ & $\begin{array}{c}(0) \\
10 \%(\mathbf{C F})\end{array}$ \\
\hline \multicolumn{6}{|c|}{ Essential amino acids (EAA) } \\
\hline Caprylic & $\cdots$ & $\cdots$ & $\cdots$ & .17 & .19 \\
\hline Myristic & $r .97$ & «.1. & 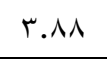 & ז.r & T.V $\varepsilon$ \\
\hline Palmatic & 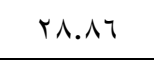 & หq. एะ & rV.TY & ro.19 & $r \leqslant . r \wedge$ \\
\hline Stearic $\left(C_{1 \wedge: .}\right)$ & 19.40 & r..Av & 11.ro & $17.7 \varepsilon$ & $1 . . V r$ \\
\hline Arachidonic &..$Y_{1}$ & 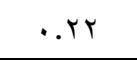 &. .41 &.$r T$ & $.1 \mathrm{~V}$ \\
\hline Total SFA & or.ru & os.or & $0 . . .7$ & 纟ุ.r. & rN.ri \\
\hline Tetradecenoic $\left(\mathrm{C}_{1 \leqslant: 1}\right)$ & $.0 \mathrm{r}$ &. .00 &. $.7 r$ &. .09 &.$\wedge 0$ \\
\hline Palmitioleic $\quad\left(C_{1 \Upsilon: 1}\right)$ & r.00 & r.01 & t.人 & r.A9 & r.sl \\
\hline Decatrienoic $\left(\mathbf{C}_{1 \curlyvee: r}\right)$ & .04 & .0 &. .00 & $.0 \leqslant$ &. $.0 \mathrm{~V}$ \\
\hline Oleic $\left(C_{\backslash_{\wedge: 1}}\right)$ & $r \varepsilon .7 V$ & (ז.r. & M.TE & rv.o. & rq.r. \\
\hline $\operatorname{Vaccinic}\left(\mathbf{C}_{\backslash \wedge: 1}\right)$ & 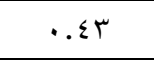 &..$\leqslant 1$ &..$\leqslant 7$ & $\cdots \varepsilon 1$ & $. T \leq$ \\
\hline Linoleic $\left(C_{\left.\right|_{\Lambda: \curlyvee}}\right)$ & r.Ar & r.09 & $\varepsilon .10$ & $0 . r$. & 11.00 \\
\hline Gamma linlenic $\left(\mathbf{C}_{\uparrow_{\wedge: \Gamma}}\right)$ &. .17 &. .17 & $.1 \mathrm{~V}$ & .17 & .11 \\
\hline Linolenic $\left(\mathbf{C}_{\backslash \wedge: \mathrm{r}}\right)$ & Tr &..$M T$ & דו &.$r \varepsilon$ &.$\wedge \mathrm{V}$ \\
\hline
\end{tabular}




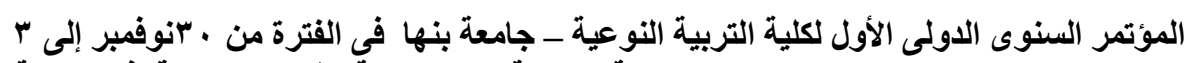

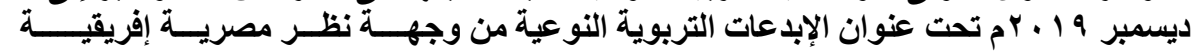

\begin{tabular}{|c|c|c|c|c|c|}
\hline Octadecatetraenoic $\left(\mathbf{C}_{\backslash_{\Lambda}: \leq}\right)$ &..$r r$ &. $\mathrm{rr}$ &.$+Y 4$ &..$\mu 1$ &. ro \\
\hline Eiosaenoic $\left(C_{Y_{1::}}\right)$ & $\cdot \varepsilon$ & 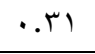 & . &. .09 & $.0 \leqslant$ \\
\hline $\operatorname{Gadoleic}\left(C_{r::\left.\right|_{\left(\omega^{9}\right.}}\right)$ & .11 & .10 & $\cdot r \cdot$ &.$r v$ & $\cdot . r \wedge$ \\
\hline Arachidonic $\left(C_{Y_{1: \leqslant}(\uparrow)}\right)$ &. $.1 T$ &. $.1 T$ & $\cdot r \cdot$ & .11 &. ro \\
\hline \multicolumn{6}{|c|}{ Odd carbon number } \\
\hline Pentaenoic $\quad\left(C_{10: .}\right)$ & $1 . r 4$ & 1.ry & 1.11 & $1.1 \mathrm{~V}$ &. .79 \\
\hline Heptadecanoic $\left(\mathbf{C}_{1 \mathrm{v}: .}\right)$ & r.00 & r.or & r.r. & t.r. & $1.0 \varepsilon$ \\
\hline Non identified FA &..$r$ & מזים &. .14 & .91 & 1.99 \\
\hline Total un SFA & $\varepsilon r .9 r$ & $\varepsilon 1.1$ & $\leqslant 7 . \leqslant 7$ & $\varepsilon 9 .+1$ & $01.0 Y$ \\
\hline KS & $\cdot . \wedge r$. & $\because v 0 \leq$ & $.9 r \wedge$ & $1 . .7$ & 1.04 \\
\hline
\end{tabular}

\section{Lipid oxidation}

Table $(\wedge)$ illustrates the peroxide values of prepared beef burgers substituted of beef fat by chickpea flour with different ratio during frozen storage at $-r \cdot{ }^{\circ} \mathrm{C}$ for three months. Peroxide value (PV) is a parameter of lipid oxidation and could be used for the evaluation of oils and fat quality.

The obtained results showed that peroxide values of prepared beef burgers was ranged from $1 . r$ to $1.0 \mathrm{~V}$ mill.equiv./Kg lipids. The highest value was found in control sample and the lowest value was in formula $(0)$. It is worthy to mention that peroxide value was reduced parallel with increasing the replacement rate of chickpea flour. This decreasing of peroxide value is mainly due to the low fat content of prepared beef burgers as shown in the previously results in table $(r)$. In addition, chickpeas has an antioxidant contents such as polyphenols and flavonoids as illustrated in the previously results in table $(r)$. Antioxidant could protect against free radical such as reactive oxygen species (Atoui et al., $r \ldots \bullet$ ). This decrease of peroxide value may be due to that chickpea contained polyphenols which has antioxidant activity (EI-Nahas, $r \ldots r$ ).

It is evident from the abovementioned results that peroxide values of all prepared burger samples were sharply increased until reached be- 


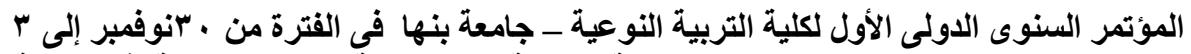

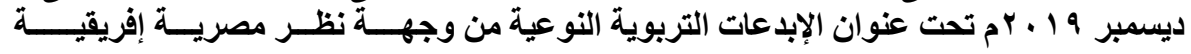

tween $1 \cdot .1$ and $1 \cdot .9$ mill.equiv./Kg lipids. at the end of storage period. The same conclusion was found by (Mehram, Eman, Y + I $V$ and Ayed, Najlh, $r+1 \wedge)$. Peroxide value was proportionally increases with the same trend, before storing. The highest peroxide value was found in control sample (without addition of chickpea), meanwhile the lowest value of PV was in formula $(r)$.

The increasing of PV during storage period may be due to the effect of free radical react with oxygen and produced hydroperoxides which are referred to as peroxides (El-Safie, $\uparrow . .$. ). In addition, frozen storage of meat was affected on the proportions of unsaturated fatty acids and phospholipids. However, the changes of lipids depend on storage time and the type of meat (El-Magoli et al, 19^r). Also, El-Nahas, $(r \ldots r)$ found that chickpeas is a good source of phenolic acids, especially, chlorogenic acid. It is obvious from the results that TBA values of prepared beef burgers were ranged from $.19 \leq$ to $\cdot r r q$ malonaldehyde/Kg sample. Control sample (without addition of chickpea) was recorded that highest value of TBA, while formulae $\left({ }^{\circ}\right)$ was the lowest value, the higher addition of chickpea flour, the lower value of TBA was noticed. This results may be due to that chickpea is considered as a good source of antioxidant contents as shown in the previously results in table $(r)$.

The abovementioned results also showed that during frozen storage period, TBA values of beef burgers were gradually increased as the prolonged time proceeded until reached between $\cdot .0 \cdot r$ and $\cdot .0 \leqslant r$. Control sample was recorded the highest value of TBA, meanwhile the lowest value was found in formula ( $\left.{ }^{\circ}\right)$ i.e. the higher addition of chickpea, the lower value of TBA was observed. This trend of results was obtained by many authors (Morcy, Hayam, $r \cdot I V$ and Al-Ajmi, Najlaa, $r \cdot I \wedge)$, they found that TBA values were increased during frozen storage of meat products. Oxidation of lipids caused an increase in TBA value during storage period. This increase could be due to instability of the malonaldehyde produced from lipid oxidation, beside microorganisms play an 


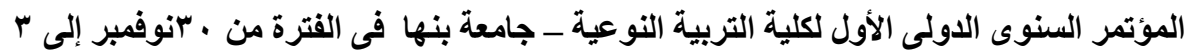

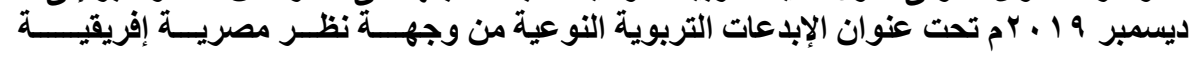

important role in decomposition of malonaldehyde (Munoz et al., $199 \wedge$ and Rhee et al, 1991 ).

It is interesting to note that TBA values of all burger samples did not reach to the permissible limits according to the Egyptian Standard Specifications, (1991) which recommended that frozen meat products should not exceed than $.9 \mathrm{mg}$ malonaldehyde/Kg sample. TBA values of prepared beef burgers were decreased as the addition level of chickpea flour increased. Moreover, chickpea has an antioxidative effect. 


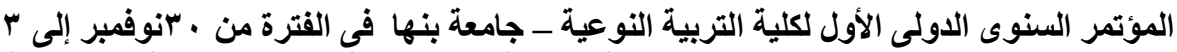

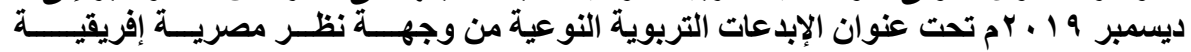

Table $(\wedge)$ : Peroxide and thiobobarbituric acid values of prepared beef burgers replaced of beef fat by chickpea flour during frozen storage replaced of beef fat by chickpea flour (CF).

\begin{tabular}{|c|c|c|c|c|c|}
\hline $\begin{array}{l}\text { Formulae } \\
\text { Storage }\end{array}$ & $\begin{array}{l}\text { (1) Con- } \\
\text { trol }\end{array}$ & $\begin{array}{l}(r) \leq \% \\
(\mathbf{C F})\end{array}$ & $\begin{array}{l}(r) \wedge \% \\
(\mathbf{C F})\end{array}$ & $\begin{array}{l}(\varepsilon) \backslash r \% \\
\text { (CF) }\end{array}$ & (0) $10 \%$ (CF) \\
\hline \multicolumn{6}{|c|}{ * Peroxide values } \\
\hline Zero time & $1.0 \mathrm{~V}$ & $1 . \leqslant Y$ & $1 . r$ & I.r & $1 . r$. \\
\hline 1- month & $0 . v$ & 0.0 & $0 . \varepsilon$ & $0 . r$ & 0.1 \\
\hline$r$ - months & $\vee . \Lambda$ & $\vee . \vee$ & $V .0$ & V.r & $v_{.}$. \\
\hline r-months & $1 \cdot .9$ & $1 \cdot v$ & $1 \cdot .7$ & $1 \cdot r$ & $1 \cdot .1$ \\
\hline \multicolumn{6}{|c|}{ ** Thiobarbituric acid values } \\
\hline Zero time &.$r r q$ & .rYV & .rI. & $\cdot r \cdot r$ & $. .19 \leq$ \\
\hline 1- month & .tAK & .rV. &.$T 0 \varepsilon$ & V & וזח. \\
\hline$r$ - months & $\cdot . \leqslant \leqslant 1$ & . &..$\leqslant Y 0$ & $\cdot .211$ & $\cdot . \varepsilon \cdot r$ \\
\hline$r$ - months & $.0 \leqslant r$ & ror & $.0 Y 0$ & $.01 \leqslant$ & $.0 . r$ \\
\hline
\end{tabular}

Microbiological changes

Total bacterial count, psychrophilic bacteria, spore forming bacteria and fungi; yeasts of prepared beef burgers replaced of beef fat by chickpea flour with different percentage during frozen storage at $-r \cdot{ }^{\circ} \mathrm{C}$ for $r$ months. The obtained results showed that total bacterial count was ranged from $r . \cdot x) \cdot{ }^{\circ}$ to $r .9 \vee \times 10^{\circ} \mathrm{cfu} / \mathrm{g}$, control sample was recorded the highest number of bacteria and the lowest number was in formula $\left({ }^{\circ}\right)$. It is evident from the results that total bacterial counts of all prepared beef burgers were decreased as the prolonged time proceeded until reached between $0.0 \times)^{.}{ }^{\xi}$ and $\vee . \wedge \times 1 .^{2} \mathrm{cfu} / \mathrm{g}$ at the end of storage. The higher level of chickpea, the lower number of total bacteria was observed. The same trend of results are in agreement with those noticed by (Emam, $r \cdots r$, Mehram, Eman, $r \cdot \mid r$ and Al-Ajmi, Najlaa, $r \cdot \mid \Lambda$ ). Freezing process reduced the growth of spoilage and pathogenic bacteria which present on meat surfaces (Sebranek et al, $r \ldots o$ and Gammarielo et al., $Y .1 \varepsilon)$. However, the growth of microorganisms leading to meat

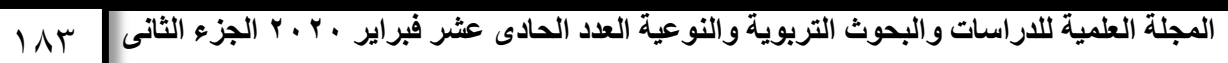




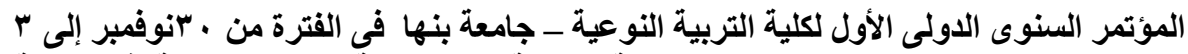

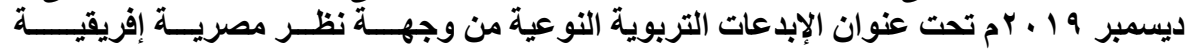

spoilage and reduced shelf-life (Sharon, $Y \cdot 17$ ). The obtained results indicated that total psychrophilic bacteria of prepared beef burgers was

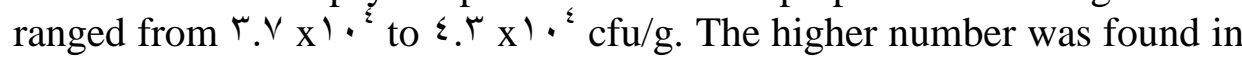
control sample and the lower was in formula $\left({ }^{\circ}\right)$. However, the high level of chickpea flour caused a decrease of total psychrophilic bacteria in both at zero time and during frozen storage period. This decrease of total psychrophilic bacteria as the addition of chickpea flour may be due to the reduction of moisture content of prepared burgers as shown in the previously results in table( $\varepsilon)$. During frozen storage period, total psychrophilic bacterial counts of all samples was slightly increased upon storage period until reached between $0.5 \times 1 .{ }^{*}$ and $\left.7.0 \mathrm{x}\right) \cdot{ }^{\varepsilon} \mathrm{cfu} / \mathrm{g}$. The higher addition of chickpea flour, the lower number of psychrophilic bacteria was observed. The same conclusion was found by Emam, $r . . r$; Mehram, Eman, $r+i v$ and Al-Ajmi , Najlaa, $(r \cdot \mid \Lambda)$.

The obtained results illustrated that spore forming bacteria of prepared beef burgers was ranged from r.. $\mathrm{x}$ 1.' to $\varepsilon .1 \mathrm{x}$ l.' $\mathrm{cfu} / \mathrm{g}$. The highest number was found in control sample and the lowest one was in formulae $(0)$. This decrease of total spore forming bacteria due to the addition of chickpea flour may be due to the reduction of moisture content during processing as shown in the previously results in table ( $\Gamma)$. Most of enterobacteria which present in meat come from fecal contamination (Du et al.,,$\ldots$ 1). The obtained results also revealed that spore forming bacteria of all prepared beef burgers were deceased during frozen storage

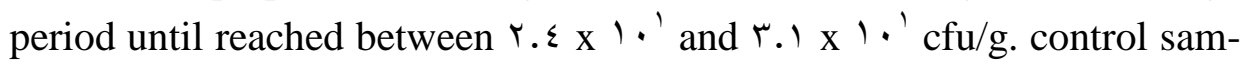
ple was recorded the highest number of spore forming bacteria, meanwhile formula ( 0 ) was the lowest number. The same trend of results are in agreement with those obtained by Emam, $(r \ldots r)$, Morcy, Hayam, $(r+\mid \vee)$ and Mehram, Eman, $(r \cdot \uparrow \vee)$. 


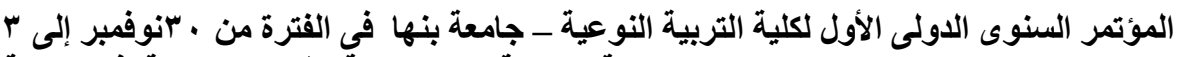

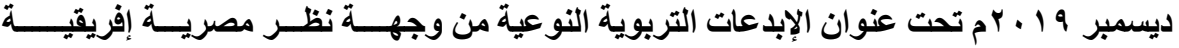

The results revealed that total fungi and yeasts was ranged from r.r $\times$ X $1 \cdot{ }^{r}$ to r.\&) $\times 1 \cdot{ }^{r} \mathrm{cfu} / \mathrm{g}$. Control sample was recorded the highest number of total fungi and yeasts, while formula $(0)$ was the lowest number. The decrease of total fungi and yeasts as a result of addition chickpea flour could be attributed that the reduced of moisture content as shown in the previously results in table $(\Gamma)$.

During frozen storage, total fungi and yeasts was slightly decreased as the prolonged time proceeded until reached between $\left.V_{.} r \times{ }^{\prime}\right)^{\prime}$ and I.Ir x $1 .{ }^{r} \mathrm{cfu} / \mathrm{g}$. The higher levels of chickpeas, the lower number of total fungi and yeasts was observed. The decrease of total fungi and yeasts during frozen storage was confirmed by Emam, $(\uparrow \ldots r)$; and Ayed, Najlh, $(r \cdot \mid \wedge)$.

Fungi and yeasts are resistant to freezing, frozen storage and also more tolerant to reduced water activity (Jay, 199

Table (9): Microbiological changes of prepared beef burgers replaced of beef fat by chickpea flour (CF) during frozen storage (cfu/g)

\begin{tabular}{|c|c|c|c|c|c|}
\hline $\begin{array}{l}\text { Formulae } \\
\text { Storage }\end{array}$ & ( 1 ) Control & $(r) \leq \%(\mathbf{F})$ & 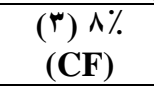 & $\begin{array}{l}\text { (\&) } 1 Y \% \\
\text { (CF) }\end{array}$ & $\begin{array}{l}(0) 10 \% \\
(\mathrm{CF})\end{array}$ \\
\hline \multicolumn{6}{|c|}{ Total bacterial count } \\
\hline Zero time & r.9V $\times 10^{\circ}$ & $\left.{ }^{r} . V^{\prime} \mathrm{X}\right) 0^{\circ}$ & $1.01 \times 10^{0}$ & $r . r \cdot x^{1} \cdot{ }^{\circ}$ & $r . x 10^{\circ}$ \\
\hline 1-month & $1.70 \times 10^{\circ}$ & $1 . \leqslant Y \times 10^{\circ}$ & $1 . r \times 10^{\circ}$ & $1.11 \times 10^{\circ}$ & $1 . \times 10^{\circ}$ \\
\hline$r$ - months & $9.1 \times 1 .{ }^{\varepsilon}$ & $\left.\vee .{ }^{\top} \mathrm{x}\right) \cdot \varepsilon$ & $7.0 \times 1.8$ & $7 . x^{1} \cdot{ }^{\varepsilon}$ & $0 . \wedge \times 1)^{\varepsilon}$ \\
\hline$r$ - months & $\vee . \wedge x)^{\prime} \cdot \varepsilon$ & $V \cdot x^{\prime} \cdot{ }^{\varepsilon}$ & $\left.7 . \mathrm{r}^{1}\right)^{\varepsilon}$ & $7.1 \times 10^{5}$ & $0.0 \times 1.8$ \\
\hline \multicolumn{6}{|c|}{ Psychrophilic bacteria } \\
\hline Zero time & $\left.\varepsilon . \Gamma^{\prime}\right)^{\prime}$ & $\varepsilon . \mid x^{2} \cdot{ }^{\varepsilon}$ & $\varepsilon \cdot x^{1 \cdot \varepsilon}$ & $\varepsilon \cdot x^{\prime} \cdot{ }^{\varepsilon}$ & r.V $\left.x^{\prime}\right)^{2}$ \\
\hline 1- month & $\left.0 . \mathrm{r}^{\prime}\right)^{2}$ & $0 . x^{1} \cdot{ }^{2}$ & $5.0 \times 10^{2}$ & $\varepsilon . \mid x^{\prime} .^{\varepsilon}$ & $\left.\varepsilon \cdot x^{1}\right)^{\varepsilon}$ \\
\hline$r$ - months & $0.7 \times 10^{2}$ & $0 . r \times 10^{\varepsilon}$ & $5.9 \times 10^{2}$ & $\varepsilon .7 \times 1)^{\varepsilon}$ & $\varepsilon .0 \times 10^{\varepsilon}$ \\
\hline$r$ - months & $7.0 \times 1 .{ }^{5}$ & $7.1 \times 1.8$ & $0 . \vee \times 10^{2}$ & $\left.0 . \mathrm{r}^{\prime}\right)^{2}$ & $0.4 \times 1.5$ \\
\hline \multicolumn{6}{|c|}{ Fungi and Yeasts } \\
\hline Zero time & $\varepsilon .1 \times 1.1$ & $r .0 \times 1 \cdot 1$ & $r . r \times 1 \cdot$ & $r . x^{\prime} \cdot 1$ & $r \cdot x^{\prime} \cdot 1$ \\
\hline 1- month & $\varepsilon \cdot x^{\prime} \cdot 1$ & $r .7 \times 1 \cdot 1$ & r.!x!. & Y.|X!.' & $r . \wedge \times 1 \cdot 1$ \\
\hline
\end{tabular}




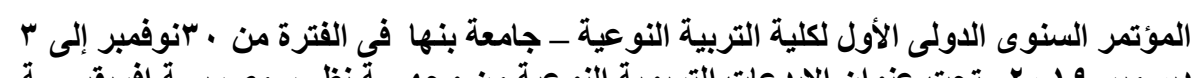

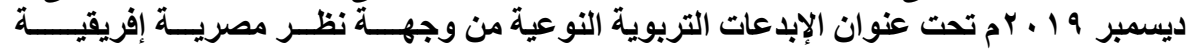

\begin{tabular}{|c|c|c|c|c|c|}
\hline$r$ - months & r. & $r . r \times 1 \cdot 1$ & $r \cdot x^{1} \cdot 1$ & Y.VXI.' & r.0 $\mathrm{X}^{1 .}$ \\
\hline$r$ - months & Y.|X|.' & $r \cdot x^{\prime} \cdot 1$ & $\left.Y . X_{X}\right) \cdot$ & Y. $\varepsilon \times 1.1$ & 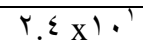 \\
\hline \multicolumn{6}{|c|}{ Spore forming bacteria } \\
\hline Zero time & $r . \Sigma \mid x^{\prime} \cdot r$ & $r . \mid r \times 1$. & $r .94 \times 1 . r$ & $4.70 \times 1 . r$ & $r . r 7 \times 1 \cdot r$ \\
\hline 1- month & $r . Y|X| \cdot r$ & $r . \wedge \vee x^{\prime} \cdot$ & $r . \leqslant 0 \times 1 \cdot r$ & $r .11 \times 1 . r$ & $r .\left|x^{\prime}\right| \cdot$ \\
\hline$r$ - months & $r .07 \times 1 . r$ & $r .\left|X^{\prime}\right| \cdot$ & $9 . \vee \times 1.1$ & $\wedge .0 \cdot x^{1} \cdot 1$ & A. $\cdot \mathrm{x}^{\prime} \cdot 1$ \\
\hline$r$ - months & $1.1 r \times 1 . r$ & $1 . \mathrm{x}^{1} \cdot r$ & $9.9 \times 1.1$ & $9.7 \times 1.1$ & $v . r \times{ }^{\prime} \cdot{ }^{\prime}$ \\
\hline
\end{tabular}

\section{Sensory evaluation}

Generally, all prepared burger formulae were recorded highly acceptable score for color, texture, taste, odor and overall acceptability by the panelists in either at zero time or at the end of storage period.Statistical analysis of the obtained data showed that there were no significant $(\mathrm{P} \leq \cdots \bullet)$ difference among all prepared beef burgers in the score of color, odor and overall acceptability in either after processing or during subsequent frozen storage period. Meanwhile, there were significant difference in both texture and taste.

Table (1.): Organoleptic evaluation score of burgers substituted of beef fat by chickpea flour $(\mathrm{CF})$ during frozen storage.

\begin{tabular}{|c|c|c|c|c|c|}
\hline $\begin{array}{l}\text { Formulae } \\
\text { Storage }\end{array}$ & (1) Control & $\begin{array}{c}(r) \\
\leqslant \%(C F)\end{array}$ & $\begin{array}{c}(\boldsymbol{r}) \\
\wedge \%(\mathbf{C F})\end{array}$ & $\begin{array}{c}(\varepsilon) \\
\mid r \%(\mathbf{C F})\end{array}$ & $\begin{array}{c}(0) \\
10 \%(C F)\end{array}$ \\
\hline \multicolumn{6}{|c|}{ Color score } \\
\hline Zero time & $\wedge . \wedge$ & A. $\vee$ & $\Lambda .7$ & $\wedge . \varepsilon$ & $* \wedge . r$ \\
\hline 1- month & ᄉ. 7 & 1.0 & $\Lambda .7$ & A.r & $* \wedge$. \\
\hline$r$ - months & $\wedge . \varepsilon$ & A.r & A.r & А.. & $* V .0$ \\
\hline$r$ - months & $\Lambda . r$ & ^.. & ᄉ.) & $* \vee . \vee$ & $* V . r$ \\
\hline \multicolumn{6}{|c|}{ Odor score } \\
\hline Zero time & 9.. & 9.1 & 9. & $9 .$. & 9.1 \\
\hline 1- month & 1.9 & $\wedge . \wedge$ & 1.9 & $\Lambda . \wedge$ & A.V \\
\hline$r$ - months & A. $\mathrm{V}$ & 1.0 & 1.0 & 1.7 & 1.7 \\
\hline r-months & $\wedge .1$ & $\wedge .1$ & $\Lambda . r$ & A.) & A.r \\
\hline \multicolumn{6}{|c|}{ Texture score } \\
\hline
\end{tabular}




\begin{tabular}{|c|c|c|c|c|c|}
\hline Zero time & 9.1 & A.V & $\Lambda . \varepsilon$ & $* \Lambda . r$ & $* \vee . \vee$ \\
\hline 1- month & 1.० & A.r & ^.. & $* V .9$ & $* \mathrm{~V} . \varepsilon$ \\
\hline$r$ - months & A.r & ^.. & V.9 & $* V . \varepsilon$ & $* V . r$ \\
\hline r-months & $* v . r$ & $*$ v. 1 & $* \mathrm{~V} .1$ & $* V$. & $* 4.1$ \\
\hline \multicolumn{6}{|c|}{ Overall acceptability score } \\
\hline Zero time & A. 1 & ᄉ. & 1.0 & ᄉ.. & $* q$. \\
\hline 1- month & ^. $\varepsilon$ & ^.乏 & 1.0 & A. $\vee$ & $\wedge . \wedge$ \\
\hline$r$ - months & $\vee . \Lambda$ & $\Lambda . r$ & ᄉ. $\varepsilon$ & 1.0 & $* \wedge . \vee$ \\
\hline r- months & $\vee .7$ & $* \gamma .0$ & $* \gamma .0$ & $* \mathrm{~V} . \varepsilon$ & $* V .0$ \\
\hline
\end{tabular}

\section{REFERENCES}

Adzitey, F.; Teye, G.A.; Boateng, R. and Dari, P.S. ( $\uparrow \cdot 10)$ : Effect of 'Prekese' (Tetrapleura tetraptera) seed powder on the sensory characteristics and nutritional qualities of pork sausage. Journal of Food Resource Science, \&(1): IV-r r.

Ahmad, S. and Nawab, Q. (Y. $(\xi)$ : Quality evaluation of fermented sausages as influenced by different fat levels and temperature of fermentation. Journal of Meat Science and Technology, $r(r): 01-7 r$.

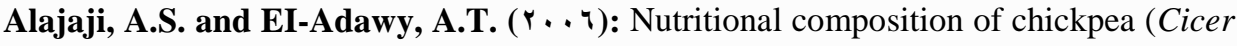
arietinum, L.) as affected by microwave cooking and other traditional cooking methods. Journal of Food Composition and Analysis, $19: \wedge \cdot \neg-\wedge)$ r.

Al-Ajmi, Najlaa, A. $(\uparrow \cdot 1 \wedge)$ : The Quality of Some Prepared Meat Products by Using Cauliflower Leaves. M.Sc. Thesis, Faculty of Specific Education, Benha University, Egypt.

Aleson-Carbonell, L.; Fernandez Lopez, J.; Perez-Alvarez, J.A. and Kuri, V. $(r \ldots \bullet)$ : Characteristic of beef burger as influenced by various types of lemon albido. Innovative Food Science and Emereg. Technol. $7: Y \leqslant \vee-r 00$.

Ali, R.F.; El-Anany, A.M. and Gaafar, A.M. ( $r \cdot 1)$ : Effect of potato flakes as fat replacer on the quality attributes of low -beef patties. International Journal Food Science Technology, r: I $\vee r-1 \wedge$.

Al-Marazeeq, K.M.; Al-Ismail, K.M. and Al-Abdullah, B.M. ( $\uparrow \ldots \wedge$ ): Evaluation of Some Chemical Properties of Different Burger Formulations. The First Interna- 


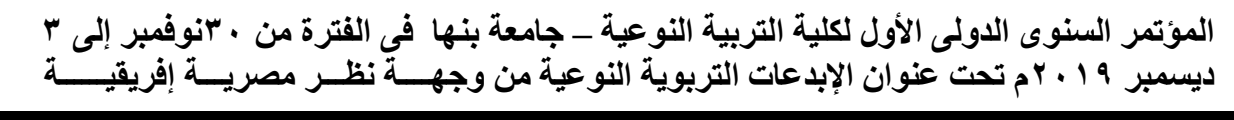

tional Conference of Food Industries and Biotechnology and Associated Fair. AlBaath University, Syria.

Al-Shemery, Fatma, H.R. ( +19$)$ : Quality of Weaning Foods Prepared by Some Vegetables. M.Sc. Thesis, Faculty of Specific Education, Benha University, Egypt.

American Association of Cereal Chemists, ( $19 \wedge \mathrm{r})$ : Approved method of AACC, Methods $\cdot \perp_{-} \cdot \wedge$ and $\varepsilon \cdot-\varepsilon \varepsilon$, approved Oct. $r \wedge,(19 \wedge 1)$ and Oct. $r \vee,(19 \wedge r)$, respectively. The Association. St. Paul, M.V.

AOAC, ( $(\cdots)$ : Official Methods of Analysis, $\mid V^{\text {th }}$ Edition, Washington, D.C. Association of Official Analytical Chemists.

AOAC, $(\uparrow \ldots \bullet)$ : Official Methods of Analysis, $1 \wedge^{\text {th }}$ Edition, Washington, D.C. Association of Official Analytical Chemists.

AOAC, $(r, 1 r)$ : Official Method of Analysis International No. 9 $\leqslant, ~ I r$ Chapter $\varepsilon, P p$. $q_{-} 1{ }^{1} .19^{\text {th }}$ Edition, Revision.

AOCS, ( $99 \wedge)$ : Official and A Tentative Methods of the American Oil Chemists Society ( $0^{\text {th }}$ ed), AOCS ro East Vaker Drive, Chicago, Illinois, USA.

Atoui, A.K.; Mansouri, A.; Boskou, G. and Kefalas, P. ( . . • ๑): Tea and herbal infu-

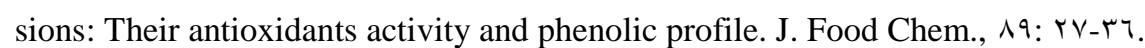

Atul, P.; Pratibha, S. and Singh, R.P. $(Y \cdot 11)$ : Evaluation of biochemical composition of desi and Kabuli chickpea (Cicer arietinum, L.) genotypes. J. Green Farming, r(O): O1 T_or.

Ayed, Najlh, T. $(r \cdot \mid \wedge)$ : Preparation and Evaluation of Sausages and Burgers by Using Broccoli During Frozen Storage. M.Sc. Thesis, Faulty of Specific Education, Benha University, Egypt.

Bligh, E.G. and Dyer, W.J. ( $19 \diamond 9)$ : A rapid method of total lipid extraction and purification. J. Biochemi. Physoil., rv: 911.

Boschin, G. and Arnolds, A. $(r+11)$ : Legumes are valuable sources of tocopherols. J. Food Chemistry, $1 r v: 1199-1 r \cdot r$.

Carrapios, A.I. ( $\uparrow \ldots \vee$ ): Effect of fat content on flavor release from sausages. J. Food

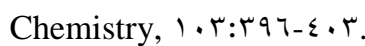

Du, W.X.; Haung, T.; Kim, J.; Marshall, M.R. and Wei, C. ( ץ. . l): Chemical, microbiological and aroma scan evaluation of mahi-mahi fillets under various storage conditions. J. Agric., Food Chem., 乏 ( ( ) : orv-or

Egyptian Standards Specifications (।१११): Frozen Sausage, Egyptian Organization for Standardization and Quality Control, Arab Republic of Egypt. 


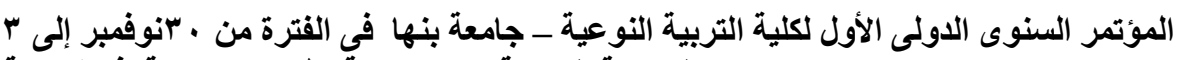

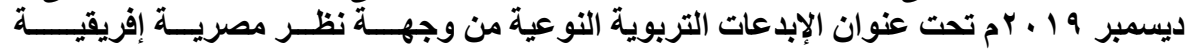

El-Magoli, S.B.; El-Wakeil, F.A. and El-Banna, H.M. ( $9 \wedge$ ץ): Effect of freezing, frozen storage and cooking on the chemical change and quality characteristics of lamp meat. Proceeding of the European Meeting of Meat Research Workers, Y $\wedge$

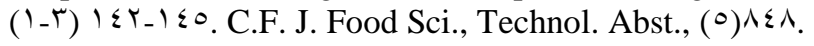

El-Nahas, O.I. $(\uparrow \ldots$ Y $)$ : A Study for the Availability of Some Anticarcinogenic Phytochemicals in Foods and Its Affect by Different Cooking and Processing Methods. Faculty of Specific Education Mansoura University, Egypt.

El-Shafie, M.E. $(\boldsymbol{Y} \cdots)$ : Chemical and Nutritional Studies on Maillard Reaction Occurred in the Cooked Fish. M.Sc. Thesis, Fac. of Home Economics, Minufiya University, Egypt.

Emam, O.A. ( $9 \wedge \vee$ ): Effect of Irradiation on Meat and Meat Products M.Sc. Thesis, Faculty of Agriculture, Ain Shams Univ., Egypt.

Emam, O.A. (199.): Effect of Irradiation on Some Food Stuffs and Their Products. Ph.D. Thesis, Faculty of Agriculture, Mansoura Univ., Egypt.

Emam, O.A. $(r \cdots r)$ : Quality-properties evaluation of burgers processed from spent laying hens meat. J. Agric. Sci., Mansoura University, Egypt, I I('): I- L צ.

FAO, $(r \ldots \vee)$ : Meat Processing Technology for Small- to Medium-Scale Producers.

FAO/WHO/UNU, (19^०): Energy and protein requirements, report of Joint FAO/WHO/UNU Expert. Consolation World Health Organization, Technical Report, Series $\vee Y \varepsilon$, WHO, Geneva.

Fernández-López, J.; Jimenéz, S.; Sayas-Barberá, E.; Sendara, E. and PérezAlvarez, J.A. ( $\uparrow \ldots \uparrow)$ : Quality characteristics of ostrich (Struthio camelus) burgers. J. Meat Science, $V$ r $(r):$ : $90-r \cdot r$.

Ferreria, R.A. dos R. and Silva, R.H. $(\uparrow \cdot \mid \wedge)$ : Evaluation of the centesimal composition of bovine burgers found in the markets of Uberaba. Hygiene Alimentary, rr

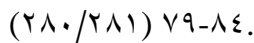

Finley, J.W.; Burrell, J.B.; and Reeves, P.G. $(\uparrow \cdots \vee)$ : Pinto bean consumption changes SCFA profiles in fecal fermentations, bacterial populations of the lower bowel, and lipid profiles in blood of humans. J. Nutr., I rV(1):

Friedman, M. (1 ११५): Nutritional value of proteins from different food sources. A

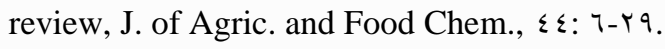




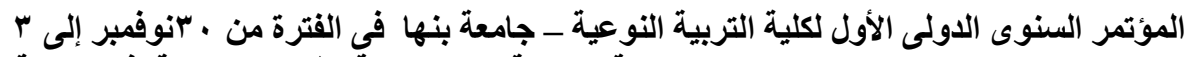

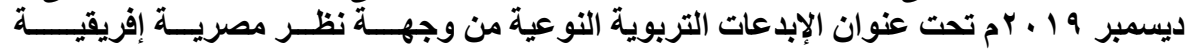

Gammarielo, D.; Incoronato, A.L.; Conte A. ; Conto , F. and Del Nobile, M.A.(Y. I \{) : A multi-step optimization approach to extend burger shelf life J.

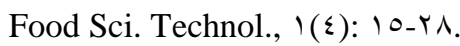

Gül, M.K.; Egesel, C.M. and Turham, H. $(\uparrow \ldots \wedge)$ : The effects of planting time on fatty acids and tocopherols in chickpea. J. European Food Research and Technology, rr т: 0IV-orr

ICMSF International Commission on Microbiological Specification for Foods ( $9 \vee \wedge)$ : Microorganism in Food Univ. of Toronto Press Toronto and Buffalo, Canada.

Jay, J.M. ( 199 ४): Low Temperature Food Preservation and Characteristics of Psychrophilic Microorganisms. In "Moden Food Microbiology" oth. ed. P.r ^^, Chapman and Hall. New York.

Kirchner, J.M.; Beasely, L.C.; Harris, K.B. and Savell, J.W. (... ) ): Evaluating the cooking and chemical characteristics of low-fat ground beef patties. J. Food Comp. Analysis, Ir:ror-rтs.

Kirlies, A.W.; Sommers, L.E. and Nelson, D.W. ( $19 \wedge$ \&): Yield, heavy metal content and milling and baking properties of soft red winter wheat grown on sols amended with sewage sludge. J. Cereal Chem.; Tl( 7$)$ : or Y_o^l.

Kumari, A.; Mane, B.G.; Thakur, D. and Khurana, S.K. ( $\uparrow \cdot 10)$ : Effect of incorporation of Lungru (Diplazium esculentum) on physico-chemical, microbiological and sensory quality of chicken patties. Journal of Meat Science and Technology, $r(Y)$ : YA-Y).

Marinangeli, C.P. and Jones, P.J. ( $(\uparrow, r)$ : Pulse grain consumption and obesity: effects on energy expenditure, substrate oxidation, body composition, fat deposition and satiety. Br. J. Nutr., 1·^:S $\leqslant$ ૫-S01.

Marioli Nobile, C.G.; Carreras, J.; Grosso, R.; Inga, M.; Silva, M.; Aguilar, R.; Allende M.J.; Badini, R. and Martinez, M.J. ( $\boldsymbol{Y} \mid \boldsymbol{\Psi})$ ): Proximate composition and seed lipid components of " Kabuli"- type chickpea (Cicer arietinum, L.) from

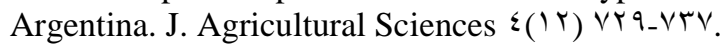

Mehram, Eman, $(Y \cdot I \vee)$ : Comparative Study Between Synthetic and Natural Antioxidant Extracted From Tomato Seeds. M.Sc. Thesis, Faculty of Specific Education, Benha, University, Egypt. 
Mendiratta, S.K.; Shinde, A.T. and Mane, B.G. $(\boldsymbol{r}, \mathrm{I} r)$ : Effect of added vegetable (carrot, radish and capsicum) as functional ingredients in mutton nuggets. Journal of Meat Science and Technology, I( $(Y): \vee 1-\vee$ T.

Morcy, Hayam, A.G. $(Y+\mid \vee)$ : Preparation of Meat Products by Using Olive leaves. Faculty of Specific Education, Benha University, Egypt.

Munoz, R.E.; Boyle, E.A. and Marsden, J.L. (19१^): Liquid smoke effects on Esherichia Coli . lov: $\mathrm{H} \vee$ and its antioxidant properties in beef products J. Food Sci., rr (1): 10.-10r.

Ordon, E.Z.; Gomez, J.D. and Vatluone, M.A. ( $\left({ }^{\prime} \uparrow^{\top}\right)$ : Antioxidant activities of

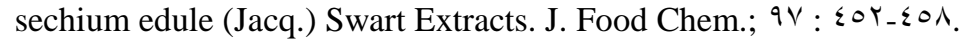

Ozvural, E.B. and Vural, H. $(\uparrow \cdots \wedge)$ : Utilization of inter esterified oil blends in the production of Frankfurters. J. Meat Science; $\vee 9(\Upsilon)$ : $\vee \Upsilon O_{-} \vee r \top$.

Rhee, K.S.; Krahl, L.M.; Lucica , L.M. and Acuff, G.R. (19१^): Antioxidative and antimicrobial effects of TBARS in aerobically refrigerated beef as related to microbial growth. J. Food Sci., ir(1): Ir. O- 1 r I.

Savell, J.W.; Harris, J.J.; Cross, H.R.; Hale, D.S. and Beasley, L.C. ( 19 १ ): Na-

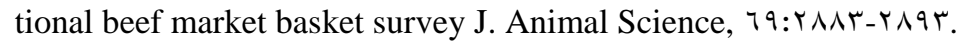

Sayago-Ayerdi, S.G.; Brenes,A. and Goni, I. ( $\uparrow \ldots q)$ : Effect of grape antioxidant dietary fiber on the lipid oxidation of raw and cooked chicken hamburgers. LWT

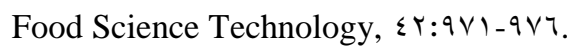

Sebranek, J.G.; Sewalt, V.J.; Robbins, K.L. and Houser, T.A. ( $\uparrow$. . ०): Comparison of a natural rosemary extract and BHA/BHT for relative antioxidant effectiveness in pork sausage. J. Meat Sci.; 79 : ҮА९_५ १ .

Serano, A.; Librelotto, J.; Cofrades, S.; Sanchez-Munize, F.J. and JimenezColmenero, F. ( $(\cdots \vee)$ : Composition and physicochemical characteristics of restructured beef steaks containing walnuts as affected by cooking method, J. Meat Sci.; $V Y(r): T \cdot \varepsilon_{-} r \mid T$.

Sharon, C. $(r \cdot 1 \uparrow)$ : Study: Handling Practices, Microbial Quality and Weight loss of Beef in Small and Medium Enterprise Butcheries in Nirobi and Isiolo Countries, Kenya M.Sc., Food Science and Technology, University of Nairobi.

Sievenpiper, J.L.; Kendall, C.W.; Esfahani, A.; Wong, J.M.; Carleton, A.J.; Jiang, H.Y.; Bazinet, R.P.;Vidgen, E. and Jenkins, D.J. ( . . ৭): Effect of non-oil-seed pulses on glycemic control: a systematic review and meta-analysis of randomised 


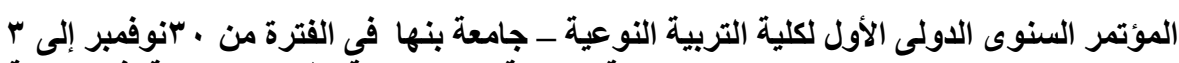

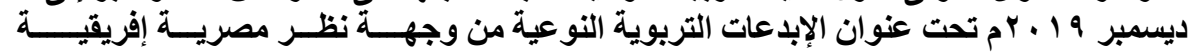

controlled experimental trials in people with and without diabetes. Diabetologia or $(\wedge): 1 \leqslant \vee 9-1 \leqslant 90$.

SPSS, ( $१ १ \wedge):$ Statistical Package for Social Science Computer Software, Ver. SPSS Company, London. Uk.

Turhan, S.; Temiz H. and Sagir, I. ( $\uparrow \ldots q)$ : Characteristic of beef patties using okra powder. Journal of Muscle Foods $\left.r \cdot(1): \wedge q_{-}\right) \cdots$.

Turhan, S.; Temiz, H. and Sagir, I. ( $\uparrow \ldots \vee)$ : Utilization of wet okra in low-fat beef patties. J. Muscle Foods, IA: rr T-rro.

USDA, $(r+1 \bullet)$ : US Dept. of Agriculture, Agricultural Research Service, Nutrient Data Labora-tory. USDA Natl. Nutrient Database for Standard Reference, Release $r \wedge$. Version Current: September $r \cdot 10$. Available from: http://ndb.nal.usda.gov/. Accessed $r \cdot 10$ December $r$.

Velie, E.M.; Schairer, C.; Flood, A.; He, J.; Khattree, R. and Schatzkin, A. ( ץ . . ๑): Empirically derived dietary patterns and risk of postmenopausal breast cancer in a

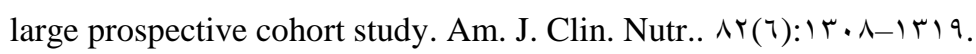

Velioglu, Y.S; Mazza, G.; Gao, L. and Oomah, B.D. ( (११^): Antioxidant activity and total phenolics in selected fruits, vegetables and grain products. J. Agric. Food Chem., $\{\tau(1 \cdot): \varepsilon \| r-\varepsilon) \backslash$.

Watts, B.M.; Yamaki, G.L.; Jeffery, L.E. and Elias, L.G. ( $१$ ११): Basic Sensory Methods for Food Evaluation. ${ }^{\text {st }} \mathrm{Ed}$. The International Development Research Center Pub. Ottawa, Canada.

Winder, K. and Egyum, ( 194 १): Description of the method used at the Department of Animal Physiology in Copenhagen. Acta Agriculture. Scandinavia; 17:117.

Xu, Y.X.; Thomas, M. and Bhardwaj, H.L. ( $\varphi_{+}(\varepsilon)$ : Chemical composition, functional properties and microstructural characteristics of three Kabuli chickpea (Cicer arietinum, L.) as affected by different cooking methods. International Journal of Food Science and Technology, $\left\{9(\varepsilon):\right.$ M $\left.10_{-}\right)$r r r.

Yang, H.; Choi, S.; Jeon, J.; Park, G. and Joo, S. ( $\uparrow+1 \vee)$ : Textural and sensory properties of low fat pork sausages with added hydrated oatmeal I and tofu as texturemodifying agents. J. Meat Sci.; $\vee \circ(r): ~ \curlyvee \wedge r-\curlyvee \wedge q$.

Zoradia, C.A.; Diego, M.; Restrepo, M. and Cortes, R. ( $\uparrow+11)$ : Vegetable products as source of dietary fiber in the food industry: a review, Revista Faulted National de Agronomia, edellin 